\title{
A novel validated UPLC method for quantitation of lopinavir and ritonavir in bulk drug and pharmaceutical formulation with its impurities
}

\author{
Gnana Deepika Killi ${ }^{1, *}$, Rama Krishna Maddinapudi ${ }^{2}$, Sathis Kumar Dinakaran ${ }^{3}$, \\ Avasarala Harani ${ }^{4}$
}

${ }^{I}$ Sri Sai Aditya Institute of Pharmaceutical Sciences and Research, Surampalem, Andhra Pradesh, India, ${ }^{2}$ Matrix Laboratories Limited, Kazhipally, Medak District, Andhra Pradesh, India, ${ }^{3}$ Aditya Institute of Pharmaceutical Sciences and Research, Surampalem, Andhra Pradesh, India, ${ }^{4}$ University College of Pharmacy, Andhra University, Visakhapatnam, Andhra Pradesh, India

\begin{abstract}
A simple gradient Ultra Performance liquid chromatographic method (UPLC) was developed for determination of lopinavir and ritonavir from its related impurities and assay for the first time. This method involves the use of a C18 (Acquity UPLC BEH C18, $50 \times 2.1 \mathrm{~mm}, 1.7 \mu \mathrm{m}$ ) column thermostated at 30 ${ }^{\circ} \mathrm{C}$ using triethylamine ( $\left.\mathrm{pH} 2.2\right): 0.1 \% \mathrm{H}_{3} \mathrm{PO}_{4}$ in acetonitrile and methanol (85:15) as mobile phase in gradient elution mode. A Photo Diode Array (PDA) detector set at $215 \mathrm{~nm}$ was used for detection with flow rate $0.4 \mathrm{~mL} / \mathrm{min}$. This method was validated over the range of limit of quantitation (LOQ) to 50 to $150 \%$ of impurity specification limit and of working concentration for assay. The developed method was validated for linearity, range, precision, accuracy and specificity. This method was successfully applied for content determination of lopinavir and ritonavir in pharmaceutical formulations. This method can be conveniently used in quality control laboratory for routine analysis for assay and related substances as well as for evaluation of stability samples of bulk drugs and pharmaceutical formulations.
\end{abstract}

Uniterms: Lopinavir/determination. Ritonavir/determination.Ultra Performance liquid chromatography/ qualitative analysis.Ultra Performance liquid chromatography/quantitative analysis. Bulk drugs/qualitative analysis. Pharmaceutical formulations/qualitative analysis. Pharmaceutical formulations/impurity profile. Bulk drugs/impurity profile.

Desenvolveu-se, pela primeira vez, método de cromatografia líquida de ultra-eficiência (UPLC), com gradiente simples, para a determinação de lopinavir e ritonavir e suas impurezas relativas. Esse método envolve o uso de $\mathrm{C} 18$ (Acquity UPLC BEH C18, $50 \times 2,1 \mathrm{~mm}, 1,7 \mu \mathrm{m}$ ), termostatizada a $30^{\circ} \mathrm{C}$, utilizandose trietilamina ( $\mathrm{pH} 2,2)$ e fase móvel de $\mathrm{H}_{3} \mathrm{PO}_{4} 0,1 \%$ em acetonitrila e metanol (85:15), em eluição por gradiente. Detector de arranjo de fotodiiodo (PDA), fixado a $215 \mathrm{~nm}$, foi utilizado para a detecção, com fluxo de $0,4 \mathrm{~mL} / \mathrm{min}$. Esse método foi validado em faixa de limite de quantificação (LOQ) de 50 a $150 \%$ de limite de impureza e da concentração de trabalho para o ensaio. O método desenvolvido foi validado quanto à linearidade, faixa, precisão, exatidão e especificidade. Esse método foi aplicado com sucesso para a determinação de lopinavir e de ritonavir em formulações farmacêuticas. Tal método pode ser convenientemente utilizado em laboratório de controle de qualidade, não só para análise de rotina e ensaio de substâncias relacionadas, como também para a avaliação da estabilidade de amostras a granel ou em formulações farmacêuticas.

Unitermos: Lopinavir/determinação. Ritonavir/determinação. Cromatografia Líquida de Ultra Eficiência/ análise qualitativa.Cromatografia Líquida de Ultra Eficiência/análise quantitativa. Fármacos a granel/ análise qualitativa. Formulações farmacêuticas/análise qualitativa.Formulações farmacêuticas/perfil de impureza. Fármacos a granel/perfil de impureza.

\footnotetext{
*Correspondence: Gnana Deepika Killi. Sri Sai Aditya Institute of Pharmaceutical Sciences and Research, Surampalem, Andhra Pradesh, India-533437. E-mail: gnanadkilli@yahoo.com
} 


\section{INTRODUCTION}

Lopinavir is an anti-Human immunodeficiency virus (HIV) drug which belongs to the class of drugs known as protease inhibitors (PIs) (Raffanti, Haas, 2001). These drugs block the activity of the HIV protease (or proteinase) enzyme to slow HIV replication and delay damage to the immune system. Lopinavir is chemically designated as [1S-[1R*, $\left.\left.\left(\mathrm{R}^{*}\right), 3 \mathrm{R}^{*}, 4 \mathrm{R} *\right]\right]-N-[4-[[(2,6-$ dimethylphenoxy)acetyl]amino]-3-hydroxy-5-phenyl-1(phenylmethyl)pentyl]tetrahydro-alpha-(1-methylethyl)2-oxo-1(2H)-pyrimidineacetamide. Its molecular formula is $\mathrm{C}_{37} \mathrm{H}_{48} \mathrm{~N}_{4} \mathrm{O}_{5}$, and its molecular weight is 628.80. Lopinavir was formulated with another protease inhibitor, ritonavir. When administered alone, lopinavir has insufficient bioavailability. However, like several other HIV protease inhibitors, its blood levels are greatly increased by low doses of ritonavir, a potent inhibitor of cytochrome P450 3A4 (Sham et al., 1998; Kumar et al., 1999) and therefore lopinavir is co-administered with sub-therapeutic doses of ritonavir by oral administration. Ritonavir is chemically designated as 10-hydroxy2-methyl-5-(1-methylethyl)-1-[2-(1-methylethyl)-4thiazolyl]-3,6-dioxo-8,11-bis(phenylmethyl)-2,4,7,12tetraazatridecan-13-oic acid, 5-thiazolylmethyl ester, [5S-(5R*, $\left.\left.8 \mathrm{R}^{*}, 10 \mathrm{R}^{*}, 11 \mathrm{R}^{*}\right)\right]$. Its molecular formula is $\mathrm{C}_{37} \mathrm{H}_{48} \mathrm{~N}_{6} \mathrm{O}_{5} \mathrm{~S}_{2}$, and its molecular weight is 720.95 . Ritonavir (RTV) is a selective, competitive and reversible inhibitor of both HIV-1 and HIV-2 proteases. It is widely used in the treatment against Acquired immunodeficiency syndrome (AIDS) and particularly to inhibit liver enzyme, viz., cytochrome P450-3A4 (CYP3A) (Yekkala et al., 2008). Lopinavir and ritonavir are freely soluble in methanol and ethanol; soluble in isopropanol and practically insoluble in water. The presence of impurities in drugs and drug products should be identified and quantified to evaluate the safety and efficacy of the drug product. In order to do this, the impurities related to the drug should be initially evaluated with the established threshold levels (ICH 2002). Therefore, it is the primary responsibility of an analytical chemist to develop and validate the method to meet the requirements of regulatory authorities. Effective method development can occur only with the cooperation of process chemists, pharmaceutical scientists and process engineers, with exhaustive review of the literature. Several High Performance Liquid Chromatography (HPLC) methods have been described in the literature for the determination of lopinavir and ritonavir individually (Yekkala et al., 2008; Dias et al., 2005; Faux et al., 2001). These are for the determination of antiretrovirals simultaneously in human plasma by
Reverse phase-HPLC: Wang et al. (2006), Rentsch, (2003), Gangl et al. (2002), and Usami et al., (2003) Two High performance liquid chromatography (HPLC) methods (Donato et al., 2006; USP, ) and one High performance thin layer chromatography (HPTLC) method (Sulebhavikar et al., 2008) were reported in the literature for determination of lopinavir and ritonavir in soft gelatin capsules and were fully validated as per International congress Harmonization (ICH) requirements. However, HPLC method reported by Donato et al. (2006) was restricted to the determination of lopinavir and ritonavir only from its degradation products and the details of degradation impurities formed under the stress conditions employed were not discussed. The literature explained the HPLC methods for the determination of related substances of lopinavir and ritonavir individually or simultaneously. All methods were carried out for long time to get good resolution between the impurity peaks. Lopinavir impurities (www.usp.org) are:

- Impurity-A [chemically $N$-\{1-benzyl-4-[2-(2,6dimethyl-phenoxy)-acetylamino]-3-hydroxy5-phenyl-pentyl \}-2-(2-oxo-tetrahydro-pyrimidin1-yl)-propionamide],

Impurity-B [chemically 3-methyl-2-(2-oxotetrahydro-pyrimidin-1-yl)-pentanoic acid $\{1-$ benzyl-4-[2-(2,6-dimethyl-phenoxy)-acetylamino]3-hydroxy-5-phenyl-pentyl $\}$ amide],

- $\quad N$-acyl impurity [chemically $N$-\{1-benzyl-4[2-(2,6dimethyl-phenoxy)-acetylamino]-3-hydroxy-5-phenyl-pentyl $\}-2-\{3-[2-(2,6-$ dimethyl-phenoxy $)-$ acetyl]-2-oxo-tetrahydro-pyrimidin-1-yl $\}-3-$ methylbutyramide],

- $O$-acyl impurity [chemically $(2,6$-dimethylphenoxy)-aceticacid $1-\{1-[2-(2,6-$ dimethylphenoxy)-acetylamino]-2-phenyl-ethyl $\}-3-[3-$ methyl-2-(2-oxo-tetrahydro-pyrimidin-1-yl)-butyryl amino]-4-phenyl-butyl ester]

- 2,6-dimethyl phenoxy acetic acid

Ritonavir impurities (www.usp.org) are:

- Impurity-F [chemically 1,3-thiazol-5-yl methyl (1S,2S,4S)-2-hydroxy-4-((4S)-4-(1-methylethyl)2,5-dioxoimidazolidin-1-yl)-5-phenyl-1 (phenylmethyl)pentyl)-carbamate],

- Impurity-I [chemically 1,3-thiazol-5-yl-methyl$((1 \mathrm{~S}, 2 \mathrm{~S}, 4 \mathrm{~S}-4-((2 \mathrm{~s})-2-(((2-\mathrm{ethyl}-1,3-$ thiazol-4yl) methyl)(methyl)amino)-carbonyl)amino-3-methylbutanoyl)amino)-2-hydroxy-5-phenyl-1-(phenylmethyl)pentyl)carbamate,

- Impurity-L [chemically (2S)-3-methyl-2(((methyl((2-(1-methylethyl)-1,3-thiazol-4-yl) 
methyl)amino)carbonyl)amino)-n-((1S)-2-((4S,5S)2-oxo-4-(phenylmethyl)-1,3-oxazolidine-5-yl)-1(phenylmethyl)ethyl)butanamide].

The aim of this current study was to develop and validate a simple gradient UPLC method for the determination of process-related impurities and degradation products, and to validate it in accordance with the ICH guidance document (ICH, 2005). This method aimed to resolve the potential impurities and degradants of lopinavir and ritonavir.

\section{MATERIAL AND METHODS}

\section{Chemicals}

HPLC grade ortho phosphoric acid and methanol procured from Merck (India) were used. HPLC grade. Triethylamine and acetonitrile were procured from Spectrochem and Qualigens respectively. HPLC grade water obtained from Millipore system (Millipore Inc., USA) was used throughout the analysis. Qualified impurity standards and drugs were obtained from Matrix Laboratories Limited, Kazhipally, Medak District, India and were used without any further purification. The water used for dilutions and making solutions was obtained through the Milli-Q water purification system available in the laboratory.

\section{UPLC Instrumentation and operating conditions}

A Waters, Acquity UPLC (Milford, MA, USA) equipped with binary solvent manager, sample manager, column heater and photodiode array detector was used. UPLC columns used in the present study were: (1) Acquity UPLC BEH C8 $1.7 \mu \mathrm{m} \times 2.1 \mathrm{~mm} \times 100 \mathrm{~mm}$; (2) Hypersil Gold $1.9 \mu \mathrm{m} \times 2.1 \mathrm{~mm} \times 50 \mathrm{~mm}$ and (3) BEH C18 1.7 $\mu \mathrm{m} \times 2.1 \mathrm{~mm} \times 50 \mathrm{~mm}$. The column BEH C18 $1.7 \mu \mathrm{m} \times 2.1$ $\mathrm{mm} \times 50 \mathrm{~mm}$ was thermostated at $30{ }^{\circ} \mathrm{C}$ was used for the separation.

\section{Analytical procedure}

Methanol was used as diluent in the preparation of analytical solutions. Lopinavir, $8 \mu \mathrm{g} / \mathrm{mL}$ and $2 \mu \mathrm{g} /$ $\mathrm{mL}$ of ritonavir working reference standard solutions were prepared using methanol. Weigh 20 tablets of each containing $200 \mathrm{mg}$ of lopinavir \& $50 \mathrm{mg}$ of ritonavir and crush them into powder. An equivalent quantity of powder was weighed and dissolved in methanol to get $4 \mathrm{mg} / \mathrm{mL}$ of lopinavir \& $1 \mathrm{mg} / \mathrm{mL}$ of ritonavir concentration and sonicate for 20 min with occasional shaking. Pass the solution through a suitable filter of $0.22-\mu \mathrm{m}$ pore size. The sample solution was stable for at least 20 hours at room temperature. Solutions of all the related substances $(0.25$ $\mathrm{mg} / \mathrm{mL}$ ) were prepared by dissolving known amounts of the substances initially in $3 \mathrm{~mL}$ of methanol and made up to the mark with diluent. These solutions were diluted further adequately to study the validation attributes. A standard solution $8 \mu \mathrm{g} / \mathrm{mL}$ of lopinavir and $2 \mu \mathrm{g} / \mathrm{mL}$ of ritonavir was spiked and it was used as system suitability solution. The specification limits used for validation studies were $0.5 \%$ for lopinavir impurities and $0.2 \%$ for ritonavir impurities with respect to the concentration of drug. Reference solution was made according to the in-house specification that is $0.2 \%$ of lopinavir and ritonavir with respect to sample concentration, $0.5 \%$ of lopinavir impurities $(0.02 \mathrm{mg} / \mathrm{mL})$ with respect to lopinavir concentration and $0.2 \%$ of ritonavir impurities $(0.002 \mathrm{mg} / \mathrm{mL})$ with respect to ritonavir concentration. Reference soluction, $3.5 \mu \mathrm{L}$, system suitability solution, blank, six replicate injections of diluted standard solution and sample solution were separately chromatographed. A resolution of not less than 2.5 and tailing factor of not more than 1.5 between ritonavir and lopinavir was set as system suitability requirement. All the known and unknown related substances were determined against mean area obtained from replicate injections of diluted standard solution.

\section{RESULTS AND DISCUSSION}

\section{Method development and separation studies on drugs and its impurities}

In all UPLC runs, the mobile phase was filtered through $0.22 \mu \mathrm{m}$ nylon membrane and degassed before use. The injection volume was $3.5 \mu \mathrm{L}$ and the analytical wavelength was set at $215 \mathrm{~nm}$, which was selected using scan mode in photodiode array detector from $200 \mathrm{~nm}$ to $400 \mathrm{~nm}$. The mobile phase flow rate was set at $0.4 \mathrm{~mL} /$ $\min$ from $0.25 \mathrm{~mL} / \mathrm{min}$, because run time was long at 0.25 $\mathrm{mL} / \mathrm{min}$. Preliminary UPLC analyses were performed using an Acquity UPLC BEH C8 $1.7 \mu \mathrm{m} \times 2.1 \mathrm{~mm} \times 100$ $\mathrm{mm}$ and Hypersil Gold $1.9 \mu \mathrm{m} \times 2.1 \mathrm{~mm} \times 50 \mathrm{~mm}$ and mobile phase composed of various buffers, acetonitrile and methanol combinations. In trial and error method, base line, resolution, system suitability requirements, peak purity, Signal to noise $(\mathrm{S} / \mathrm{N})$ ratio and response factor did not meet the acceptance criteria. This led to the further development of the method to resolve the drug and impurities peaks. The mobile phase was then modified to 
obtain a final composition of the mobile phase at different time. The flow rate and injection volumes were $0.4 \mathrm{~mL} /$ min and $3.5 \mu \mathrm{L}$ respectively. The analysis was carried out under gradient conditions as follows, time $(\mathrm{min}) / \mathrm{A}(\mathrm{v} / \mathrm{v}): \mathrm{B}$ (v/v); T0.01/65:35, T3.0/50:50, T5.0/50:50, T10.0/20:80, $\mathrm{T} 11.0 / 65: 35$ and $\mathrm{T} 12.0 / 65: 35$. The data was acquired at $215 \mathrm{~nm}$ for $12 \mathrm{~min}$ and processed by use of Empower Pro data handling system. The UPLC runs using the modified method ended with the required resolution of all peaks along with the good baseline and good signal to noise ratio. The final method was then optimized with the above mobile phase conditions with the use of a BEH C18 $1.7 \mu \mathrm{m} \times 2.1 \mathrm{~mm} \times 50 \mathrm{~mm}$ Column, keeping the column temperature at $30^{\circ} \mathrm{C}$. Sample temperature was maintained at $5^{\circ} \mathrm{C}$. The degradants were finally resolved with required resolution.

In the final method, mobile phase A was prepared by dissolving $2 \mathrm{~mL}$ of triethylamine in $1000 \mathrm{~mL}$ of water and $\mathrm{pH}$ was adjusted to $2.2 \pm 0.05$ using orthophosphoric acid. $0.1 \%$ ortho phosphoric acid in acetonitrile and methanol (85:15) was used as mobile phase B. Here, ortho phosphoric acid was used to improve the response of peaks by decreasing signal to noise ratio; triethylamine was used to increase the sharpness of peaks and for good resolution; $85: 15$ ratio of mobile phase was used to minimize the time of elution of both peaks and to resolve peaks with good resolution. Selection of wavelength was based on the overlap spectra. Though $\lambda \max$ of drugs and impurities was at 210 and $211 \mathrm{~nm}$, due to solvent effect, the wavelength was set at $215 \mathrm{~nm}$. Column temperature was set at $30^{\circ} \mathrm{C}$ for good baseline and clear separation of all peaks. Sample temperature was maintained at $5{ }^{\circ} \mathrm{C}$ because of instability of drug at room temperature. Laboratory batches of reference standard of lopinavir and ritonavir along with impurities and the formulation were analyzed using the UPLC method. The optimized method expressed that all the peaks were eluting with required resolution and baseline was good with good signal to noise ratio. All the peaks were well distributed throughout the run time. The final method minimized the Blank interference and was optimized by the validation parameters.

\section{System suitability}

From the system suitability studies, resolution between ritonavir and lopinavir was 6.56; tailing factor, theoretical plate and peak area for lopinavir and ritonavir were $1.07 \& 1.05,57299.87 \& 22485.28$ and 162956 $\& 32209$ respectively. The result of system suitability satisfied the suitability parameters.

\section{Validation parameters}

\section{Specificity}

A solution of $0.05 \mathrm{mg} / \mathrm{mL}$ of lopinavir, 0.05 $\mathrm{mg} / \mathrm{mL}$ of ritonavir, $0.5 \%$ with respect to lopinavir concentration of lopinavir impurities $(0.02 \mathrm{mg} / \mathrm{mL})$ and $0.2 \%$ with respect to ritonavir concentration of ritonavir impurities $(0.002 \mathrm{mg} / \mathrm{mL})$ was prepared and was injected individually and as coinjection to check the coelution of peaks for specificity. The resolution between the peaks corresponding to impurities and drugs were also studied for method specificity. Figure 1 and Table I demonstrate the method of specificity in which lopinavir, ritonavir and its impurities were well resolved with a resolution of more than 2.32 and with no interference with the drug peak, indicating that the method was selective and specific for its intended use.

\section{Linearity}

The linearity of the method was studied with different concentrations of $20 \%, 40 \%, 60 \%, 80 \%, 100 \%$, $120 \%$ and $150 \%$ of reference solutions $(1.6,3.2,4.8,6.4$, 8.0, 9.6 and $12 \mu \mathrm{g} / \mathrm{mL}$ for lopinavir and $0.4,0.8,1.2,1.6$, 2.0, 2.4 and $3 \mu \mathrm{g} / \mathrm{mL}$ for ritonavir). Each concentration was injected in duplicate into UPLC system. Regression parameters were summarized for Linearity. The linearity of peak areas versus different concentrations was evaluated for lopinavir, ritonavir and its impurities using 7 levels ranging 20 to $150 \%$ with respect to reference solution. The linear regression data for all the components tested were presented in Table II. The linear data confirmed that the detector response at $215 \mathrm{~nm}$ was linear over the ranges studied for all components. The linearity results for lopinavir, ritonavir and their known impurities in the specified concentration range were found satisfactory, with a correlation coefficient greater than 0.990 .

\section{Limits of detection and quantitation (LOD and LOQ)}

The quantification limit and detection limit of impurities and the drug were determined by diluting known concentrations of each impurity and drugs until signal-to-noise ratios were obtained at about 10:1 and 3:1 respectively as per ICH guideline. The LOD and LOQ values of lopinavir were $0.332 \mu \mathrm{g} / \mathrm{mL}$ and $0.831 \mu \mathrm{g} / \mathrm{mL}$; for ritonavir, $0.488 \mu \mathrm{g} / \mathrm{mL}$ and $1.22 \mu \mathrm{g} / \mathrm{mL}$; for lopinavir impurities, from 0.425 to $1.353 \mu \mathrm{g} / \mathrm{mL}$; and for ritonavir impurities, from 0.785 to $1.24 \mu \mathrm{g} / \mathrm{mL}$ respectively. The results were depicted in Table II. The results indicate that the method was capable of detecting and quantifying the 


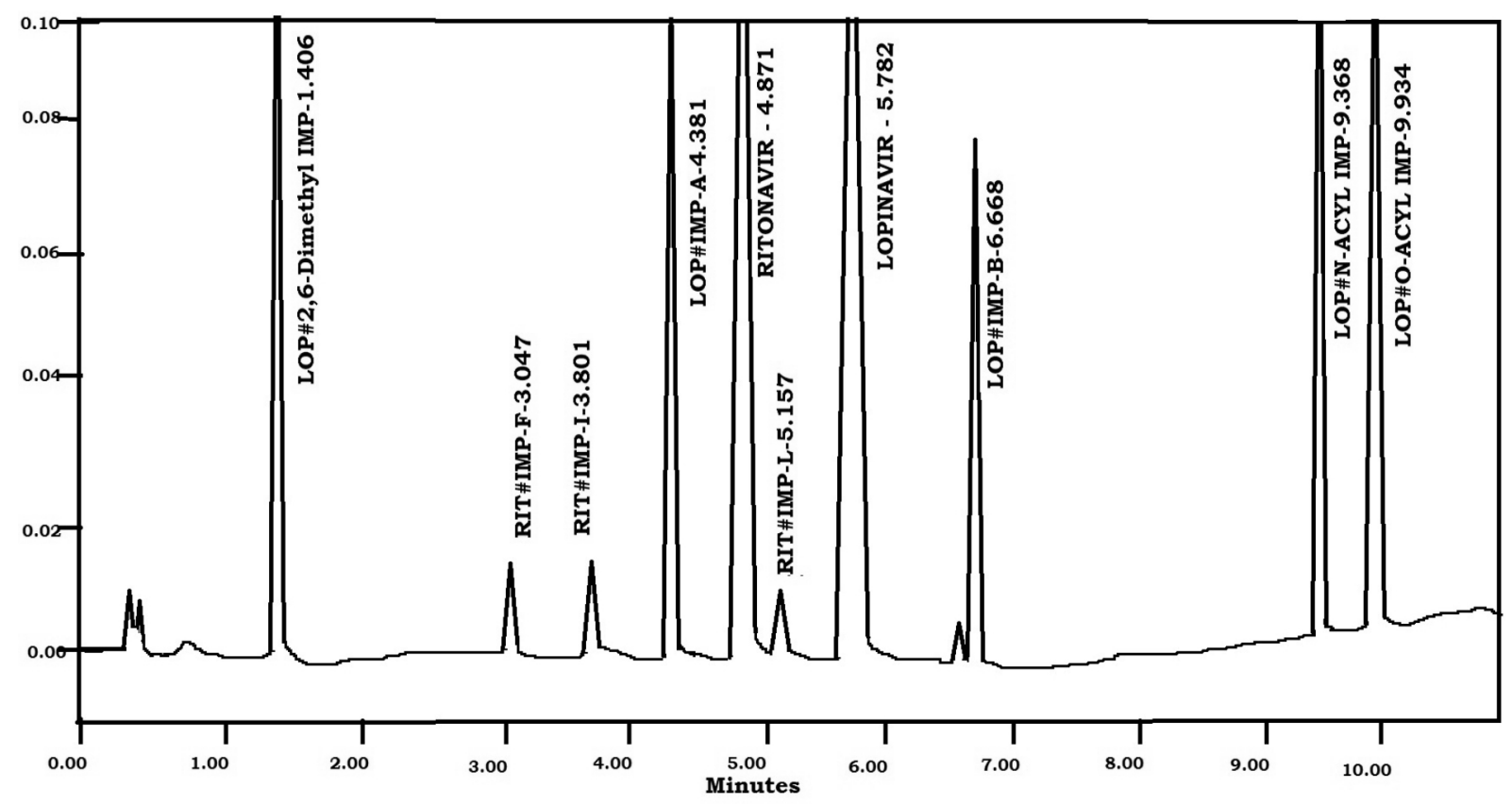

FIGURE 1 - Chromatogram of lopinavir, ritonavir and its impurities.

TABLE I - Specificity results

\begin{tabular}{lccccc}
\hline S.NO. & Component & RT (minutes) & RRT & USP Resolution & USP Asymmetry \\
\hline 1 & 2,6-dimethyl Imp & 1.406 & 0.243 & - & 1.06 \\
2 & Impurity-F & 3.047 & 0.527 & 20.11 & 1.04 \\
3 & Impurity-I & 3.801 & 0.657 & 9.70 & 1.05 \\
4 & Impurity-A & 4.381 & 0.758 & 6.62 & 1.10 \\
5 & Ritonavir & 4.871 & 0.842 & 4.46 & 1.11 \\
6 & Impurity-L & 5.157 & 0.892 & 2.32 & 1.10 \\
7 & Lopinavir & 5.782 & 1.000 & 5.03 & 1.06 \\
8 & Impurity-B & 6.668 & 1.153 & 8.27 & 1.09 \\
9 & N-Acyl Imp & 9.368 & 1.620 & 34.15 & 1.11 \\
10 & O-Acyl Imp & 9.934 & 1.718 & 8.32 & 1.10 \\
\hline
\end{tabular}

$\mathrm{RT}=$ Retention time; $\mathrm{RRT}=$ Relative retention time; $\mathrm{USP}=\mathrm{U} . \mathrm{S}$. Pharmacopeia

impurities in reliably low concentrations.

\section{Precision}

System precision was verified using diluted standard solution, which was analyzed for six times and Percentage Relative Standard deviation (\%RSD) of lopinavir and ritonavir peak areas was evaluated and was found to be $1.0 \%$. The precision of the method was demonstrated using a repeatability test. Repeatability was evaluated by measuring the peak responses of six replicate injections. The overall \%RSD was evaluated and was found to be in the range of $0.29-0.64 \%$ for all related substances, which were within the acceptance criterion of Not more than (NMT) $10.0 \%$ RSD. The results are presented in Table III.

\section{Accuracy (recovery)}

Accuracy of the method for all known impurities was determined by analyzing lopinavir and ritonavir sample solutions spiked with all the known substances at three different concentration levels of 50, 100 and $150 \%$ of each in triplicate at the specified limit at LOQ and reference level. The recovery of all known substances were found to be in-between the predefined acceptance criterion of 89.61 to $108.22 \%$ and the data is given in Table III. 
TABLE II - data for Linearity, LOD and LOQ

\begin{tabular}{llccccccc}
\hline \multirow{2}{*}{ Component } & \multicolumn{3}{c}{ Linearity } & \multicolumn{3}{c}{ LOQ } & \multicolumn{4}{c}{ LOD } \\
\cline { 2 - 9 } & Regression equation & $\mathrm{R}^{2}$ & $\begin{array}{c}\text { Concentration } \\
(\mu \mathrm{g} / \mathrm{mL})\end{array}$ & $\begin{array}{c}\text { Signal to } \\
\text { Noise Ratio }\end{array}$ & $\begin{array}{c}\text { LOQ } \\
(\%)\end{array}$ & $\begin{array}{c}\text { Concentration } \\
(\mu \mathrm{g} / \mathrm{mL})\end{array}$ & $\begin{array}{c}\text { Signal to } \\
\text { Noise Ratio }\end{array}$ & $\begin{array}{c}\text { LOD } \\
(\%)\end{array}$ \\
\hline Lopinavir & $\mathrm{Y}=2428468 \mathrm{X}+2313$ & 0.9867 & 0.831 & 10.14 & 0.0208 & 0.3324 & 2.46 & 0.00831 \\
2,6-Dimethyl Imp & $\mathrm{Y}=26564813 \mathrm{X}+22578$ & 0.9923 & 0.576 & 7.52 & 0.0144 & 0.2304 & 2.64 & 0.00576 \\
Impurity-A & $\mathrm{Y}=17540731 \mathrm{X}+26187$ & 0.9900 & 0.954 & 10.34 & 0.0239 & 0.3816 & 3.27 & 0.00954 \\
Impurity-B & $\mathrm{Y}=13864026 \mathrm{X}+25985$ & 0.9849 & 1.353 & 10.19 & 0.0338 & 0.5412 & 2.37 & 0.01353 \\
N-Acyl Imp & $\mathrm{Y}=27245620 \mathrm{X}+44274$ & 0.9866 & 0.425 & 9.03 & 0.0106 & 0.1700 & 2.61 & 0.00425 \\
O-Acyl Imp & $\mathrm{Y}=21720629 \mathrm{X}+30441$ & 0.9909 & 0.536 & 10.06 & 0.0134 & 0.2144 & 3.12 & 0.00536 \\
Ritonavir & $\mathrm{Y}=16927565 \mathrm{X}+983$ & 0.9878 & 1.220 & 10.20 & 0.1220 & 0.4880 & 2.81 & 0.04880 \\
Impurity-F & $\mathrm{Y}=16012737 \mathrm{X}+1589$ & 0.9907 & 0.927 & 10.00 & 0.0927 & 0.3708 & 2.99 & 0.03708 \\
Impurity-I & $\mathrm{Y}=14253667 \mathrm{X}+105$ & 0.9927 & 0.785 & 8.41 & 0.0785 & 0.3140 & 2.37 & 0.03140 \\
Impurity-L & $\mathrm{Y}=13355523 \mathrm{X}+438$ & 0.9820 & 1.240 & 8.62 & 0.1240 & 0.4960 & 2.53 & 0.04960 \\
\hline
\end{tabular}

TABLE III - Precision and \% recovery data.

\begin{tabular}{lccccccccc}
\hline \multirow{2}{*}{ Component } & \multicolumn{3}{c}{ Precision } & \multicolumn{3}{c}{$\%$ recovery at LOQ level } & \multicolumn{2}{c}{ \% recovery at Reference level } \\
\cline { 2 - 10 } & $\begin{array}{c}\text { Average } \\
\text { peak area }\end{array}$ & $\begin{array}{c}\text { Standard } \\
\text { Deviation }\end{array}$ & \% RSD & $50 \%$ & $100 \%$ & $150 \%$ & $50 \%$ & $100 \%$ & $150 \%$ \\
\hline 2,6-Dimethyl Imp & 18774.63 & 53.77 & 0.29 & 104.76 & 107.99 & 91.78 & 91.61 & 107.44 & 107.61 \\
Impurity-A & 13839.29 & 67.86 & 0.49 & 101.88 & 101.68 & 100.98 & 90.18 & 100.03 & 100.22 \\
Impurity-B & 17020.21 & 51.02 & 0.30 & 97.52 & 93.21 & 96.33 & 93.16 & 93.00 & 92.89 \\
$N$-Acyl Imp & 20477.25 & 111.16 & 0.54 & 92.57 & 91.90 & 94.03 & 90.14 & 103.97 & 108.22 \\
O-Acyl Imp & 9922.76 & 63.40 & 0.64 & 90.14 & 101.45 & 104.58 & 90.09 & 107.99 & 107.69 \\
Impurity-F & 11472.41 & 67.41 & 0.59 & 108.98 & 91.61 & 107.00 & 104.45 & 104.99 & 99.75 \\
Impurity-I & 19949.00 & 113.09 & 0.57 & 106.57 & 90.25 & 108.05 & 100.03 & 108.16 & 100.48 \\
Impurity-L & 15533.60 & 81.00 & 0.52 & 107.31 & 90.42 & 105.56 & 93.54 & 104.55 & 102.54 \\
\hline
\end{tabular}

\section{Robustness}

The robustness of the method was studied by small but deliberate changes to mobile phase flow, column oven temperature and $\mathrm{pH}$. The effects of these changes were tested on the drug spiked with reference solution. The parameters selected were $\mathrm{pH}$ of the mobile phase $( \pm 0.2$ units), flow rate $( \pm 0.1 \mathrm{~mL} / \mathrm{min})$, and column temperature $\left( \pm 2{ }^{\circ} \mathrm{C}\right)$. Only one parameter was changed while the others were kept unaltered. The difference between robustness values from the actual optimized condition results was found to be below $10.0 \%$. The studies indicated that there was no effect on the determination of related substances and the selectivity. Therefore, the test method was robust for the quantification of related substances.

\section{CONCLUSION}

The proposed method is simple, rapid and selective. Percent Relative standard Deviation was very low, below $2.0 \%$, which indicate that the method is highly precise. Short Analysis time ( $\leq 12 \mathrm{~min})$ coupled with simplicity and ease of operation warrants use of the method for analysis of lopinavir, ritonavir and its known impurities stated above in Bulk as well as in Formulated dosages for Assays and for said known impurities by UPLC. Therefore, the method can be useful in routine quality Control analysis in bulk.

\section{ACKNOWLEDGEMENT}

The authors thank VSP Prasad (Senior Vice- 
President) and Analytical R\&D, Matrix Laboratories Limited, Kazhipally, Medak District for their support to complete this research.

\section{REFERENCES}

Available at http://www.usp.org/sites/default/files/usp_pdf/EN/ USPNF/pending-Standards/2010-04-m4119.pdf, retrieved on $01 / 03 / 2012$. You must identify the data and include the citation. Include also the access data.

DIAS, C.L.; ROSSI, R.C,; DONATO, E.M.; BERGOLD, A.M.; FROEHLICH, P.E. LC Determination of ritonavir, a HIV protease inhibitor, in soft gelatin capsules. Chromatographia, v.62, p.589-593, 2005.

DONATO, E.M.; DIAS, C.L.; ROSSI, R.C.; VALENTE, R.S.; FRÖEHLICH, P.E.; BERGOLD, A.M. LC Method for studies on the stability of lopinavir and ritonavir in soft gelatin capsules. Chromatographia, v.63, p.437-443, 2006.

FAUX, J.; VENISSE, N.; OLIVIER, J.C.; BOUQUET, S. Rapid high-performance liquid chromatography determination of lopinavir, a novel HIV-1 protease inhibitor, in human plasma. Chromatographia, v.54, p.469-473, 2001.

GANGL, E.; UTKIN, I.; GERBER, N.; VOUROS, P. Structural elucidation of metabolites of ritonavir and indinavir by liquid chromatography-mass spectrometry. J. Chromatogr. A., v.974, p.91-101, 2002.

INTERNATIONAL CONFERENCE ON HARMONIZATION. ICH Guideline, Q2(R1). Validation of analytical procedures, text and methodology, November 2005.

\section{INTERNATIONAL CONFERENCE ON HARMONIZATION.}

ICH. Technical Requirements for Registration of Pharmaceuticals for Human Use. Impurities in new drug substances., Q3A (R1). 2002.

KUMAR. G.N,; JAYANTI, V.; LEE, R.D.; WHITTERN, D.N.; UCHIC, J.; THOMAS, S,; JOHNSON, P., GRABOWSKI, B., SHAM, H., BETEBENNER, D., KEMPF, D.J., DENISSEN, J.F. In vitro metabolism of the HIV-1 protease inhibitor ABT-378: species comparison and metabolite identification. Drug Metab. Dispos., v.27, p.86-91, 1999.
RAFFANTI, S.; HAAS, D.W. Antimicrobial agents: antiretroviral agents. In: HARDMAN, J.G.; LIMBIRD, L.E.; GILMAN, A.G. (Eds.). Goodman and Gilman's: the pharmacological basis of therapeutics. 10.ed. New York: McGraw-Hill; 2001. p.1349-1380.

RENTSCH, K.M. Sensitive and specific determination of eight antiretroviral agents in plasma by high-performance liquid chromatography-mass spectrometry. J. Chromatogr. B, v.788, p.339-350, 2003.

SHAM, H.L.; KEMPF, D.J.; MOLLA, A.; MARSH, K.C.; KUMAR, G.N.; CHEN, C.M.; KATI, W.; STEWART, K.; LAL, R.; HSU, A.; BETEBENNER, D.; KORNEYEVA, M.; VASAVANONDA, S.; MCDONALD, E.; SALDIVAR, A.; WIDEBURG, N.; CHEN, X.; NIU, P.; PARK, C.; JAYANTI, V.; GRABOWSKI, B.; GRANNEMAN, G.R.; SUN, E.; JAPOUR, A.J.; LEONARD, J.M.; PLATTNER, J.J.; NORBECK, D.W. ABT-378, a highly potent inhibitor of the human immunodeficiency virus protease. Antimicrob. Agents Chemother., v.42, p.3218-3224, 1998.

SULEBHAVIKAR, A.V.; PAWAR, U.D.; MANGOANKAR, K.V.; PRABHU NAVELKAR, N.D. HPTLC method for simultaneous determination of lopinavir and ritonavir in capsule dosage form. E-J. Chem., v.5, p.706-712, 2008.

USAMI, Y.; OKI, T.; NAKAI, M.; SAGISAKA, M.; KANEDA, T. A simple HPLC method for simultaneous determination of lopinavir, ritonavir and efavirenz in plasma. Chem. Pharm. Bull., v.51, p.715-718, 2003.

WANG, P.G.; WEI, J.S.; KIM, G.; CHANG, M.; ELSHOURBAGY, T. Validation and application of a high-performance liquid chromatography-tandem mass spectrometric method for simultaneous quantification of lopinavir and ritonavir in human plasma using semiautomated 96-well liquid-liquid extraction. J. Chromatogr. A., v.1130, p.302-307, 2006.

YEKKALA, R.S.; ASHENAFI, D.; MARIEN, I.; XIN, H.; HAGHEDOOREN, E.; HOOGMARTENS, J.; ADAMS, E. Evaluation of an international pharmacopoeia method for the analysis of ritonavir by liquid chromatography. $J$. Pharm. Biomed. Anal., v.48, p.1050-1054, 2008.

Received for publication on $02^{\text {th }}$ May 2013 Accepted for publication on $30^{\text {th }}$ September 2013 
